\title{
Environmental Risk of Pesticides
}

\author{
Deepa Hada* and Kanika Sharma \\ Department of Botany, Mohanlal Sukhadia University, Udaipur-313001 (Rajasthan), India
}

Submission: February 03, 2018; Published: March 26, 2018

*Corresponding author: Deepa Hada, Department of Botany, Mohanlal Sukhadia University, Udaipur-313001 (Rajasthan), India, Email: deepahada.hada52@gmail.com

\section{Introduction}

Pesticides are found in the environment in all over the World. Use of pesticides on a large scale started during the 1950 s and 1960s. They are widely used in most sectors of the agricultural production to prevent or reduce losses by pests and thus can improve yield as well as the quality of the produce, which is often important to consumers [1]. It can also improve the nutritional value of food and sometimes its safety. The authorities and the users were then not aware of the dangers of using pesticides as regards to dispersal and side effects in the environment. Serious concerns about health risk arising from the exposure of pesticides to farmers when mixing and applying pesticides or working in treated fields and from residues of food and in drinking water [2]. These activities have caused a number of accidental poisonings, and even the routine use of pesticides can pose major health risks to farmers both in the short and the long run and can degrade the environment. They can enter into food chain cause several deleterious effects on human as well as wildlife health and also be the cause of environmental pollution [3].

\section{Dispersal of pesticides}

The dispersal of pesticides in the environment depends to a large extent on the chemical and physical properties of the compounds, such as molecular structure, water pressure, solubility in water, stability and adsorption properties [4].

\section{Safe handling of pesticides}

Pesticides can, of course, be found within the areas where they are used. A great problem is the undesired further distribution of pesticides in nature, causing pollution of water areas and the groundwater [5]. It is now known that unsatisfactory management of pesticides at filling and cleaning of spraying equipment causes point sources of pollution of surface water and groundwater, as well as large areas of soils [6]. Experiences from many countries have shown that point sources of pesticides are one of the most dominant reasons behind pesticide pollution of rivers, streams, lakes, groundwater and local water supplies [7]. However, the use of simple units (e.g. biobeds) can minimise the risks of pollution when filling spraying equipment. Many countries have started training programmes for farmers to teach them about safe handling of pesticides [8].

\section{Pesticide registration and safety}

Pesticide registration is a scientifically based, legal, and also administrative process, where a wide variety of effects associated with the use of a pesticide product and its potential effect on human health and the environment is assessed [9]. The registration is an important step in the management of pesticides as it enables authorities primarily to determine which pesticide products are permitted to be used and for what purposes, and also to exercise control over quality, usage rates, claims, labelling, packaging and advertising of pesticides, thus ensuring that the best interest of end users, as well as the environment, are well protected [10].

\section{Human exposure to pesticides and factors affecting exposure}

Human exposure to pesticides may occur through occupational exposure in the case of agricultural workers in open fields and greenhouses, workers in the pesticide industry, and exterminators of house pests [11]. The exposure of workers increases in the case of not paying attention to the instructions on how to use the pesticides and particularly when they ignore basic safety guidelines on the use of personal protective equipment and fundamental sanitation practices such as washing hands after pesticide handling or before eating [12].

\section{Pesticide and human health}

Risk assessment of pesticide impact on human health is not an easy and particularly accurate process because of differences in the periods and the levels of exposure, type of pesticides (regarding toxicity), mixtures or cocktails used in the field, and the geographic and meteorological characteristics of the agricultural areas where pesticides are applied [13].

\section{Minimizing the negative impact of pesticides}

Despite continuing disagreements over the degree of risk posed by pesticides, it appears that people have become increasingly concerned about pesticide use and particularly about their impacts on human health and environmental quality [14]. These increased concerns resulted mainly from reduced trust in the agricultural and industrial methods of production as well as on the authority's regulations aimed at protecting both 
the environment and human health [15]. Therefore, considering the existence of several uncertainties in the evaluation of pesticide safety, scientific data, policy guidelines, and professional judgment must be incorporated when estimating whether a pesticide can be used beneficially within the limits of an acceptable risk [16].

\section{Conclusion}

Pesticides have played a key role in providing reliable supplies of agricultural produce at prices affordable to consumers, improving the quality of produce, and ensuring high profits to farmers. Although pesticides are developed to function with reasonable certainty and minimal risk to human health and the environment, many studies have raised concerns about health risks from exposure of farmers and from non-occupational exposure of the population to residues found on food and drinking water. Several indicators have been used to assess the potential risk of pesticides to human health and the environment. However, their use indicated reduced certainty, suggesting the need for the development of alternative indicators that should increase the accuracy and reliability of pesticide risk assessment and thus contribute to the reduction of the possible adverse effects of pesticides on human health and the environment.

\section{Acknowledgement}

One of the authors (Deepa Hada) is thankful to University Grant Commission (UGC), New Delhi, India, for providing financial assistance.

\section{Conflict of Interest}

The authors declare that there is no economic interest and no conflict of interest regarding the publication of this article.

\section{References}

1. Boxall RA (2001) Post-harvest losses to insect - a world overview. Int Biodeter Biodegr 48: 137-152.

2. Cooper J, Dobson H (2007) The benefits of pesticides to mankind and the environment. Crop Prot 26: 1337-1348.
3. Ecobichon DJ (2001) Pesticide use in developing countries. Toxicology 160(1-3): 27-33.

4. Narayanasamy P (2007) Postharvest Pathogens and Disease Management; John Wiley \& Sons, New York, NY, USA.

5. Wilson C, Tisdell C (2001) Why farmers continue to use pesticides despite environmental, health and sustainability costs. Ecol Econ 39: 449-462.

6. Damalas CA (2009) Understanding benefits and risks of pesticide use. Sci Res Essays 4: 945-949.

7. Van der Werf HMG (1996) Assessing the impact of pesticides on the environment. Agr Ecosyst Environ 60: 81-96.

8. Zyoud SH, Sawalha AF, Sweileh WM, Awang R, Al-Khalil SI, et al. (2010) Knowledge and practices of pesticide use among farm workers in the West Bank, Palestine: Safety implications. Environ. Health Prev Med 15: 252-261.

9. Oerke EC, Dehne HW (2004) Safeguarding production-losses in major crops and the role of crop protection. Crop Prot 23: 275-285.

10. Maroni M, Fanetti AC, Metruccio F (2006) Risk assessment and management of occupational exposure to pesticides in agriculture. Med Lav 97: 430-437.

11. Recena MC, Caldas ED, Pires DX, Pontes ER (2006) Pesticides exposure in Culturama, Brazil-knowledge, attitudes, and practices. Environ Res 102: $230-236$

12. Isin S, Yildirim I (2007) Fruit-growers' perceptions on the harmful effects of pesticides and their reflection on practices: The case of Kemalpasa, Turkey. Crop Prot 26: 917-922.

13. Damalas CA, Georgiou EB, Theodorou MG (2006) Pesticide use and safety practices among Greek tobacco farmers: A survey. Int. J. Environ. Health Res 16: 339-348.

14. Pimentel D (2005) Environmental and economic costs of the application of pesticides primarily in the United States. Environ Dev Sustain 7: 229-252.

15. Soares WL, Porto MD (2009) Estimating the social cost of pesticide use: An assessment from acute poisoning in Brazil. Ecol Econ 68: 27212728.

16. Damalas CA, Theodorou MG, Georgiou EB (2006) Attitudes towards pesticide labelling among Greek tobacco farmers. Int J Pest Manage 52: 269-274.

\section{Your next submission with Juniper Publishers} will reach you the below assets

- Quality Editorial service

- Swift Peer Review

- Reprints availability

- E-prints Service

- Manuscript Podcast for convenient understanding

- Global attainment for your research

- Manuscript accessibility in different formats

( Pdf, E-pub, Full Text, Audio)

- Unceasing customer service

Track the below URL for one-step submission https://juniperpublishers.com/online-submission.php 